\section{Loyalitas Kreativitas \\ Aldi Masyarakat Kreatif}

P-ISSN 2722-2101, E-ISSN 2722-4201

Program Studi Ekonomi Manajemen Universitas Pamulang

Jurnal LOKABMAS Kreatif Vol. 01, No. 03, Hal. 81-86

Email:jurnalkreatif.manajemen@gmail.com

\title{
PENGABDIAN KEPADA MASYARAKAT \\ BAKTI SOSIAL DAN PELATIHAN \\ BUDIDAYA LELE DAN KANGKUNG \\ SKALA RUMAH TANGGA DALAM MASA PANDEMI COVID- 19
}

\author{
Agus Mulyono, Agus Nurrokhman, Wuguh Pitono, Aod Abdul Jawad, \\ Nova Wisnianingsih
}

Dosen Teknik Industri Fakultas Teknik Universitas Pamulang

Email:

Dosen02255@unpam.ac.id, dosen02221@unpam.ac.id, dosen02514@unpam.ac.id, dosen02273@unpam.ac.id, dosen02276@unpam.ac.id

\begin{abstract}
ABSTRAK
Kegiatan Pengabdian Kepada Masyarakat ini bertujuan dalam rangka memenuhi kewajiban dalam pelaksanaan Tri Darma Perguruan Tinggi dan untuk meringankan sedikit beban berupa pembagian bingkisan sembako dan pelatihan budidaya lele dan kangkung dalam skala kecil keluarga kepada beberapa keluarga di daerah Desa Sukamulya Kecamatan Cikupa Kabupaten Tangerang yang terkena dampak ekonomi secara langsung akibat wabah Covid-19.

Hasil kegiatan PKM menunjukan bahwa permasalahan mitra, dengan adanya pandemic covid 19 yang mengakibatkan mereka tidak mendapatkan penghasilan seperti pedagang kecil, informal, ojol dan supir. Kami berinisiatif membantu program pemerintah dalam meringankan beban masyarakat khususnya masyarakat menengah kebawah yang sangat terpengaruh dengan adanya wabah covid 19 ini, dengan memberikan bantuan sembako sebagai bentuk langsung yang bias dikonsumsi untuk meringankan beban saudara kita yang terkena dampak virus corona

Metode kegiatan yang digunakan adalah melakukan kerjasama dengan pengurus RT25 RW09 Mulya Asri 2 Sukamulya Cikupa Tangerang. Sebelum kegiatan dilaksanakan, kami melakukan komunikasi awal dengan pengurus lingkungan setempat yang kemudian dilakukan survei lapangan untuk mengetahui kondisi riil masayarakat dan mengidentifikasi keluarga sasaran dalam pelaksanaan kegiatan PKM. Setelah mendapatkan data keluarga yang memenuhi kriteria sebagai sasaran maka komunikasi lanjutan kepada pengurus lingkungan dalam menetukan waktu pelaksanaan dan teknis kegiatan.
\end{abstract}

Kata kunci : Covid-19, pelatihan, ekonomi, budidaya

\section{ABSTRAC}

This Community Service activity aims in order to fulfill the obligations in the implementation of Tri Darma Higher Education and to ease the burden in the form of the distribution of food parcels and training of catfish and kale cultivation in small-scale families to some families in sukamulya village area of Cikupa District tangerang district directly affected by the Covid-19 outbreak.

The results of PKM activities show that partner problems, with the covid-19 pandemic resulting in them not earning such as small traders, informals, ojol and drivers. We take the initiative to assist the government program in alleviating the burden on the community, especially the lower middle class who are severely affected by this covid-19 outbreak, by 
Loyalitas Kreativitas

Aldi Masyarakat Kreatif
P-ISSN 2722-2101, E-ISSN 2722-4201

Program Studi Ekonomi Manajemen Universitas Pamulang

Jurnal LOKABMAS Kreatif Vol. 01, No. 03, Hal. 81-86

Email:jurnalkreatif.manajemen@gmail.com

providing food assistance as a direct form of bias consumed to ease the burden of our relatives affected by the coronavirus

The method of activity used is to cooperate with the board of RT25 RW09 Mulya Asri 2 Sukamulya Cikupa Tangerang. Prior to the activity, we conducted initial communication with local environmental administrators who then conducted a field survey to find out the real condition of masayarakat and identify the target family in the implementation of PKM activities. After obtaining family data that meets the criteria as a target, follow-up communication to environmental administrators in setting the implementation time and technical activities.

\section{Keywords : Covid-19, training, economy, cultivation}

\section{PENDAHULUAN}

Pandemi wabah covid-19 yang melanda dunia dan tidak terkecuali Indonesia telah ikut menurunkan derajat kemampuan keuangan para keluarga dan masyarakat secara luas. Gelombang PHK tidak dapat dihindarkan sebagai akibat produksi dan konsumsi di berjalan secara normal. Para pekerja ekonomi di sektor informal juga mengalami kebuntuan penghasilan karena akses dan aktifitasnya sangat terbatas terlebih pada masa PSBB (pembatasan sosial berskala besar) yang diterapkan pemerintah. Adanya penurunan dari sektor ekonomi, baik di perdagangan maupun perindustrian, pandemic covid-19 dan berlakunya PSBB, maka yang berjualan dan yang membeli berkurang. Yang akibatnya ekonomi masyarakat pun perputarannya saat ini sangat menurun karena banyak orang yang kehilangan pekerjaannya.

Mengingat Indonesia masih terdapat banyak garis-garis kemiskinan diberbagai daerah dengan kondisi serba kekurangan dan keterbatasan ditengah wabah covid-19 membuat kesejahteraan masyarakat secara tidak langsung akan mengalami penurunan. Akibatnya, masih banyak masyarakat kecil dan kurang mampu mengalami berbagai hambatan seperti kebutuhan finansial yang kurang dalam membeli kebutuhan pokok dan sebagainya dapat dikatakan belum menjalani kehidupan secara layak.
Apalagi kesejahteraan masyarakat berkaitan erat dengan masalah kesehatan khususnya kalangan masyarakat kecil kebawah saat ini di uji akibat adanya wabah covid-19 seperti contohnya berupa vitamin dan obat-obatan yang dimana stok persediaan dirumah mereka saja tidak ada sama sekali bahkan masih belum mendapatkan perhatian dari pemerintah setempat. Dengan adanya wabah covid-19 yang bisa saja mereka terserang kapan saja apabila tidak ditangani secara cepat oleh pemerintah. Menjadi tanggungjawab dan tugas bersama untuk memberikan bantuan dan menunjukkan kepedulian sesama dalam meringankan beban yang dirasakan. Bantuan ekonomi langsung berbentuk langsung berupa misalnya bahan pokok dan lainnya sangat membantu dan hal yang sangat dibutuhkan. Kegiatan pemberdayaan ekonomi masyarakat adalah salah satu hal yang dibutuhkan pada mas krisis ekonomi seperti saat ini. Bentuk-bentuk kegiatan pemberdayaan tersebut adalah :

a. Membangkitkan harga diri kaum dhuafa, membangkitkan harga diri ini dapat dilakukan seperti mana yang dilakukan oleh Rasulullah Sollallohualaihiwassallam adalah dengan mendekatkan diri dan bergaul dengan mereka. Mereka perlu mendapatkan perhatian, penghargaan, pujian, kegembiraan, kemuliaan, doa, kasih sayang dan lainnya.

b. Memberikan motivasi, hal ini diperlukan untuk memacu semangat berusaha dan bekerja bagi kaum dhuafa. 
Loyalitas Kreativitas

Aldi Masyarakat Kreatif
P-ISSN 2722-2101, E-ISSN 2722-4201

Program Studi Ekonomi Manajemen Universitas Pamulang

Jurnal LOKABMAS Kreatif Vol. 01, No. 03, Hal. 81-86

Email:jurnalkreatif.manajemen@gmail.com c. Memberikan pelatihan yang bisa menopang kemandiriaan yang sesuai dengan kemampuan mereka

d. Memberikan jaminan dan bantuan sosial untuk meringankan beban keluarga terdampak.

Berdasarkan latar belakang tersebut, kami dari Tim Program Pengabdian Masyarakat (PKM) Universitas Pamulang (UNPAM) yang berjumlah 5 dosen terpanggil untuk ikut serta membantu memecahkan persoalan yang dihadapi oleh masyarakat Mulya Asri 2, Sukamulya Cikupa Tangerang dengan mengadakan bakti sosial dan pelatihan ketrampilan sederhana dalam meringankan beban ekonomi dan ketahan ekonomi keluarga dengan judul "Bakti Sosial dan Pelatihan Budidaya Lele dan Kangkung Dalam Skala Rumah Tangga dalam Masa Pandemi Covid-19"

\section{RUMUSAN MASALAH}

Berdasarkan analisa situasi di atas maka dapat diperoleh rumusan masalah yang dihadapi masyarakat yang terdampak covid19 adalah :

1. Bagaimana solusi meringankan beban ekonomi bagi warga Mulya Asri Sukamulya Cikupa Tangerang dalam masa pandemic Covid-19?

2. Bagaimana solusi yang bersifat jangka menengah yang mampu membantu menumbuhkan ketahanan ekonomi keluarga dalam masa pandemic Covid19 ?

\section{TUJUAN PELAKSANAAN}

Berdasarkan rumusan masalah yang ada maka tujuan dari Pengabdian Kepada Masyarakat ini adalah :

1. Untuk memberikan bantuan secara langsung untuk meringankan beban ekonomi dalam wabah Covid-19.

2. Untuk memberikan pelatihan sederhana dalam membantu ketahanan ekonomi keluarga dalam wabah Covid-19.

\section{TINJAUAN PUSTAKA}

\section{Definisi Bakti Sosial}

Berdasarkan data situs worldmeter per 5 mei 2020, penderita positif virus corona seluruh dunia sudah mencapai 3,669 juta dengan jumlah kasus meninggal 253,183 dan yang sembuh 1,210 juta. Berdasarkan data per 5 mei 2020 gugus tugas percepatan penanganan covid-19, total jumlah penderita positif corona di Indonesia mencapai 12.071 orang. Jumlah ini bertambah sebanyak 484 orang dari jumlah hari sebelumnya. Jumlah kasus baru ini juga tertinggi sejak 21 maret 2020. Dampak wabah covid-19 kepada perekonomian dunia sangat dahsyat, berdasarkan pertumbuhan year-on-year sumber pertumbuhan ekonomi Indonesia pada triwulan 1-2020 terbesar sektor informasi dan komunikasi sebesar 0,53\%. Hal ini wajar mengingat dengan adanya anjuran untuk tidak keluar rumah maka banyak orang yang akhirnya kehilangan pekerjaan mereka.

Untuk itu kami selaku dosen manajemen Universitas Pamulang melakukan kegiatan pengabdian kepada masyarakat dengan berbagi sembako kepada masyarakat yang membutuhkan. Dalam rangka kegiatan pengabdian kepada masyarakat ini kami melakukan kerja sama dengan pengurus lingkungan RT 25 Mulya Asri 2 Desa Sukamulya Cikupa Tangerang, pada bakti sosial dan pelatihan ketrampilan dalam pemberdayaan ekonomi keluarga untuk membantu ditengah kesulitan ekonomi sebagai akibat pandemic covid 19.

\section{Tujuan Bakti Sosial dan Pelatihan}

Atas dasar analisis kejadian tersebut solusi yang diberikan terhadap mitra yang merupakan keluarga yang terdampak ekonomi di lingkungan RT 25 RW 09 Mulya Asri 2 Desa Sukamulya Cikupa Tangerang adalah jangka pendek dan jangka menengah. Jangka pendek dengan memberikan bingkisan dengan tujuan awal ingin meringankan sedikit beban dalam pemenuhan kebutuhan pokok sehari-hari serta memberikan pelatihan budidaya lele 
Loyalitas Kreativitas

Aldi Masyarakat Kreatif
P-ISSN 2722-2101, E-ISSN 2722-4201

Program Studi Ekonomi Manajemen Universitas Pamulang

Jurnal LOKABMAS Kreatif Vol. 01, No. 03, Hal. 81-86

Email:jurnalkreatif.manajemen@gmail.com dan kangkung yang dapat dikonsumsi anggota keluarga dan juga mungkin dapat bernilai ekonomi yang berkelanjutan.

\section{Manfaat Bakti Sosial dan Pelatihan}

Membangun jiwa solidaritas dan rasa moralitas yang tinggi salah satu caranya yaitu dengan menumbuhkan rasa empati terhadap orang lain, selain itu juga dengan menjalin silahturahmi dengan orang lain dengan cara rutin melakukan komunikasi demi menjadi tali silahturahmi yang intensif dengan individu atau kelompok lain. Selain itu manfaat dari kegiatan ini adalah untuk membantu pemberdayaan masyarakat, menurut Ginanjar Kartasasmita, pemberdayaan masyarakat adalah upayaupaya untuk meningkatkan harkat dan martabat lapisan masyarakat yang dalam kondisi sekarang tidak mampu untuk melepaskan diri dari perangkap kemiskinan dan keterbelakangan. Dengan kata lain memberdayakan adalah memampukan dan mamandirikan masyarakat.

\section{METODE PELAKSANAAN}

Atas dasar analisis kejadian tersebut solusi yang diberikan terhadap mitra yang merupakan keluarga yang terdampak ekonomi di lingkungan RT 25 RW 09 Mulya Asri 2 Desa Sukamulya Cikupa Tangerang adalah jangka pendek dan jangka menengah. Jangka pendek dengan memberikan bingkisan dengan tujuan awal ingin meringankan sedikit beban dalam pemenuhan kebutuhan pokok sehari-hari serta memberikan pelatihan budidaya lele dan kangkung yang dapat dikonsumsi anggota keluarga dan juga mungkin dapat bernilai ekonomi yang berkelanjutan.

Membangun jiwa solidaritas dan rasa moralitas yang tinggi salah satu caranya yaitu dengan menumbuhkan rasa empati terhadap orang lain, selain itu juga dengan menjalin silahturahmi dengan orang lain dengan cara rutin melakukan komunikasi demi menjadi tali silahturahmi yang intensif dengan individu atau kelompok lain. Selain itu manfaat dari kegiatan ini adalah untuk membantu pemberdayaan masyarakat, menurut Ginanjar Kartasasmita, pemberdayaan masyarakat adalah upayaupaya untuk meningkatkan harkat dan martabat lapisan masyarakat yang dalam kondisi sekarang tidak mampu untuk melepaskan diri dari perangkap kemiskinan dan keterbelakangan.

\section{HASIL DAN PEMBAHASAN}

Pemberian bantuan bingkisan secara langsung dalam bentuk sembako telah mampu memberikan semangat dan motivasi bahwa rasa gotong rotong dan kepedulian terhadap sesama masih terpelihara dan hidup, ini memberikan bukti nyata bahwa ikatan persaudaraan sebagai anak bangsa khususnya keluarga besar Universitas Pamulang siap hadir di tengah masyarakat.

Pelatihan budidaya lele dan kangkung dengan disertai benih dan sarana yang diperlukan telah memberikan ketrampilan baru dan sebuah asa dalam menatap dan menghadapi tantangan kehidupan khususnya pada masa ekonomi sulit sebagai akibat pandemic covid 19. Pemberian pelatihan budidaya ini juga dapat membangun kemandirian ekonomi berkelanjutan bila secara ekonomi bernilai dalam skala yang lebih besar.

Untuk lebih jelasnya, tahapan kegiatan PKM ini dapat dijelaskan melalui gambar berikut ini :

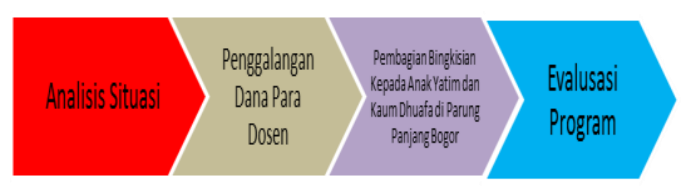

Gambar : Tahapan Kegiatan PKM

Luaran yang diharapkan dalam program ini adalah membantu program pemerintah dalam meringankan beban masyarakat khususnya masyarakat menengah kebawah yang sangat terpengaruh dengan adanya wabah covid-19 ini, dengan memberikan bantuan langsung berupa sembako selain itu kami memberikan pelatihan budidaya yang dapat membangun kemandirian ekonomi 
Loyalitas Kreativitas

Aldi Masyarakat Kreatif
P-ISSN 2722-2101, E-ISSN 2722-4201

Program Studi Ekonomi Manajemen Universitas Pamulang Jurnal LOKABMAS Kreatif Vol. 01, No. 03, Hal. 81-86

Email:jurnalkreatif.manajemen@gmail.com berkelanjutan bila secara ekonomi bernilai dalam skala yang lebih besar.

Ada beberapa strategi pemberdayaan masyarakat yang bisa menjadi pilihan dalam melaksanakan pemberdayaan masyarakat antara lain :

1. Strategi dengan tiga pendekatan, yaitu :

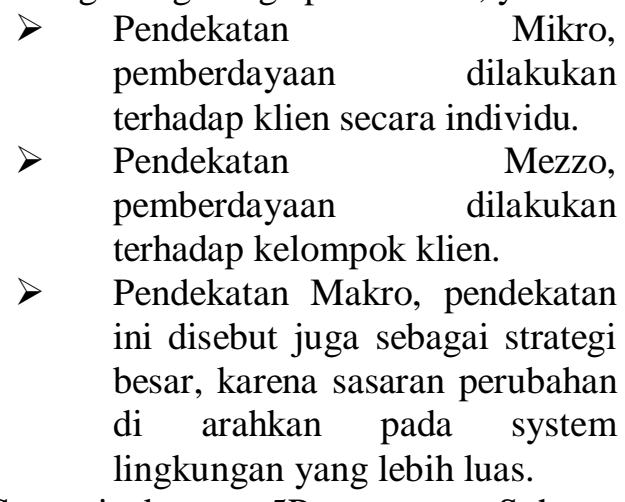

2. Strategi dengan 5P, menurut Suharto dalam Oos M. Anwas 30 yaitu : pemungkinan, penguatan, perlindungan, penyokongan dan pemeliharaan.

\section{KESIMPULAN DAN SARAN}

\section{Kesimpulan}

Dengan terlaksananya kegiatan pengabdian kepada masyarakat dengan memberikan bantuan langsung berupa sembako dan pelatihan budidaya lele dan kangkung beserta benih dan sarananya kepada beberapa keluarga terdampak Covid 19 di lingkungan RT 25 RW 09 Mulya Asri 2 Sukamulya Cikupa Tangerang, kami mengucapkan rasa syukur Alhamdulillah kepada Allah SWT, sehingga kegiatan ini berjalan sesuai dengan yang kita harapkan. Begitu juga terima kasih kepada seluruh pihak yang turut serta dalam pelaksanaan kegiatan ini.

\section{Saran}

Saran dalam pengabdian kepada masyarakat ini yaitu diharapkan untuk dapat mempersiapkan kegiatan ini dengan matang sehingga penggalian dana lebih besar sehingga skala jumlah keluarga yang diberikan bantuan dan pelatihan bisa lebih luas.

\section{DAFTAR PUSTAKA}

AM Irfanudin, D Sunardi, R Sari, I Imbron, N Nariah. (2020). PERAN SEO DALAM MENINGKATKAN RELIABILITAS PEMASARAN PRODUK VIA MEDIA ONLINE PADA FORUM MUSLIMAH DEPOK. Dedikasi PKM, 1(1)

Elburdah, R. P., \& Oktrima, B. (2020). PENGARUH COMMUNITY OF PRACTICE PADA IMPLEMENTASI KNOWLEDGE MANAGEMENT PADA KANTOR KELURAHAN REMPOA. JURNAL LOKABMAS KREATIF, 1(2), 11-15.

Pasaribu, V. L. D., Susanti, F., \& Hartuti, E. T. K. (2019). Memotivasi Siswa dan Siswi SMK Letris Indonesia di Dalam Menentukan Pilihan Untuk Melanjutkan Pendidikan Atau Bekerja Setelah Lulus Sekolah. Jurnal Pengabdian Dharma Laksana, 1(2), 161-172.

Pasaribu, V. L. D., Elburdah, R. P., Sudarso, E., \& Fauziah, G. (2020). PENGGUNAAN MANAJEMEN WAKTU TERHADAP PENINGKATAN PRESTASI BELAJAR DI SMP ARAISIYAH. Jurnal ABDIMAS Tri Dharma Manajemen, 1(1).

Pasaribu, V. L. D., Agrasadya, A., Shabrina, N., \& Krisnaldy, K. (2020). MENJADI ENTERPRENEUR MUDA YANG MEMILIKI JIWA LEADERSHIP UNTUK MENGHADAPI MASA DEPAN. Abdi Laksana, 1(1).

Pasaribu, V. L. D., Sulaiman, S., Sutiman, S., Thaharudin, T., \& Purnomo, B. Y. (2020). PENGENALAN LETAK POSYANDU TERDEKAT DIKELURAHAN PISANGAN DENGAN MANAJEMEN PEMASARAN REVOLUSI 4.0 UNTUK MENINGKATKAN PENGETAHUAN MASYARAKAT LETAK DAN FUNGSI POSYANDU TERDEKAT PADA KELURAHAN PISANGAN. DEDIKASI PKM, 1(1), 105-110.

Priadi, A., Pasaribu, V. L. D., Virby, S., Sairin, S., \& Wardani, W. G. (2020). PENGUATAN EKONOMI KREATIF BERBASIS SUMBER DAYA DESA 
Loyalitas Kreativitas

Aldi Masyarakat Kreatif
P-ISSN 2722-2101, E-ISSN 2722-4201

Program Studi Ekonomi Manajemen Universitas Pamulang Jurnal LOKABMAS Kreatif Vol. 01, No. 03, Hal. 81-86

Email:jurnalkreatif.manajemen@gmail.com
DIKELURAHAN REMPOA. Abdi

Laksana, 1(3), 356-35

Pasal 4 ayat (1) Undang- Undang Dasar Negara Repubik Indonesia Tahun 1945

UU No.6 Tahun 2018 tentang Karantina Kesehatan (Lembaga Negara Republik Indonesia Tahun 2018 Nomor 128, Tambahan Lembaran Negara Republik Indonesia Nomor 6236);

Peraturan Pemerintah Republik Indonesia Nomor 21 Tahun 2020 Tentang Pembatasan Sosial Berskala Besar Dalam Rangka Percepatan Penanganan Corona Virus Disease 2019 (covid-19)

Keputusan Presiden Republik Indonesia Nomor 11 tahun 2020 Tentang penetapan kedaruratan kesehatan masyarakat corona virus disease 2019 (covid-19)

Peraturan Gubernur Nomor 27 tahun 2020 tentang Pedoman PSBB

Jurnal.id (2019, Maret 12). Retrieved from

https://jurnal.id:https://www.jurnal.id /id/blog/strategi-bisnis-untuk-bersaing https://tirto.id/pertumbuhanekonomi-minus-catatan-buruk-krisisekonomi-ri-9798-eKbR

"Ramai Soal Budikdamber, Berikut Cara Ternak Lele dan Tanam Kangkung dalam Ember", https://www.kompas.com diakses 5 April 2020

Belajar Budikdamber, yuk! Teknik Budidaya Ikan \& Tanaman yang Viral namun

Bermanfaat, https://www.99.co/blog/indonesia/teknikbudikdamber-lele/

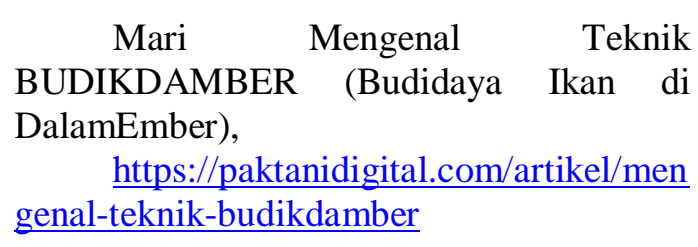

\section{DOKUMENTASI FOTO KEGIATAN}
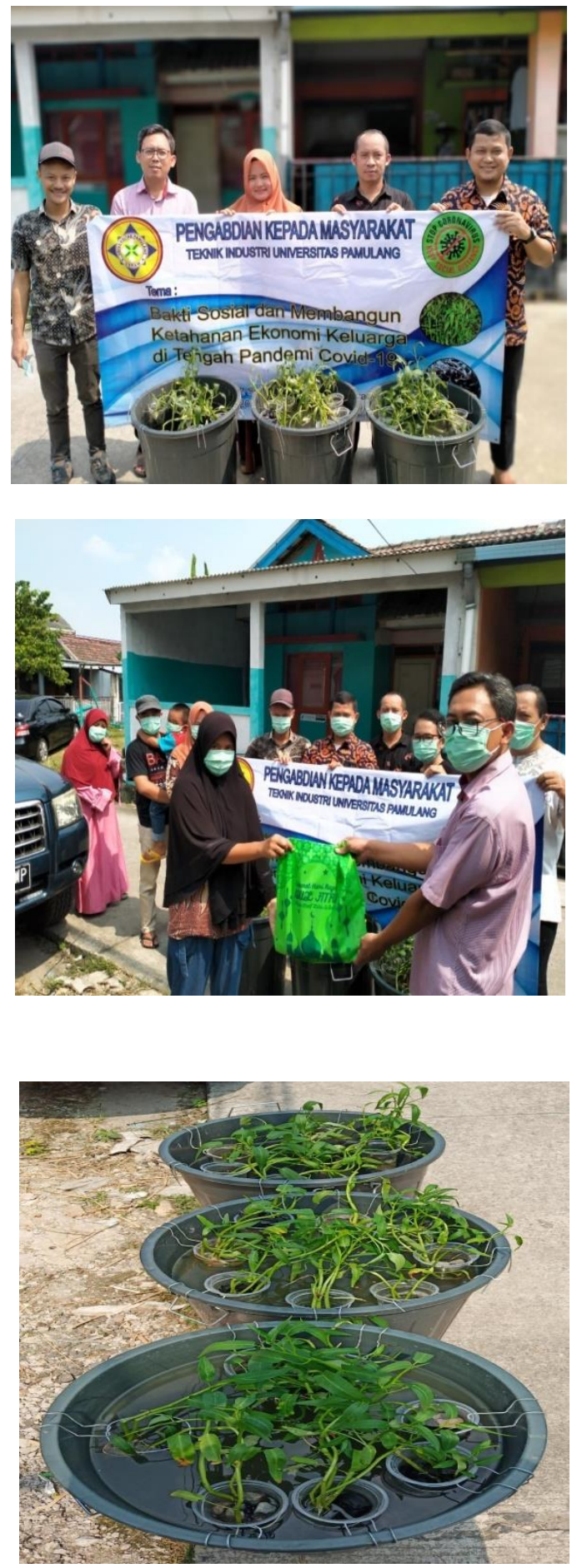